New Materialisms 



\section{New Materialisms}

Ontology, Agency, and Politics

EDITED BY

DIANA COOLE AND SAMANTHA FROST

DUKE UNIVERSITY PRESS Durbam \& London 2010 
(C) 2010 Duke University Press

All rights reserved

Printed in the United States of America on acid-free paper $\infty$ Designed by Jennifer Hill

Typeset in C \& C Galliard by Keystone Typesetting, Inc.

Library of Congress Cataloging-in-Publication Data appear on the last printed page of this book. 
To our children, Lucien, Simon, and Madeleine, who are growing up in a new materialist world, and to Shirley Margaret Coole (1923-2009) and Michèle A. Moriarty (1952-2009), who did not see the end of the project but live on in memory. 
